\title{
Chapter 1 \\ Introduction: New Approaches \\ to Sustainable Offshore Food Production \\ and the Development of Offshore \\ Platforms
}

\author{
Poul Holm, Bela H. Buck and Richard Langan
}

\begin{abstract}
As we exhaust traditional natural resources upon which we have relied for decades to support economic growth, alternatives that are compatible with a resource conservation ethic, are consistent with efforts to limit greenhouse emissions to combat global climate change, and that support principles of integrated coastal management must be identified. Examples of sectors that are prime candidates for reinvention are electrical generation and seafood production. Once a major force in global economies and a symbol of its culture and character, the fishing industry has experienced major setbacks in the past half-decade. Once bountiful fisheries were decimated by overfishing and destructive fisheries practices that resulted in tremendous biomass of discarded by-catch. Severe restrictions on landings and effort that have been implemented to allow stocks to recover have had tremendous impact on the economy of coastal communities. During the period of decline and stagnation in capture fisheries, global production from aquaculture grew dramatically, and now accounts for $50 \%$ of the world's edible seafood supply. With the convergence of environmental and aesthetic concerns, aquaculture, which was already competing for space with other more established and accepted uses, is having an increasingly difficult time expanding in nearshore waters. Given the
\end{abstract}

\footnotetext{
P. Holm (ه)

School of Histories and Humanities, Trinity College Dublin,

2 College Green, Dublin 2, Ireland

e-mail: holmp@tcd.ie

B.H. Buck

Marine Aquaculture, Maritime Technologies and ICZM, Alfred Wegener

Institute Helmholtz Centre for Polar and Marine Research (AWI),

Bussestrasse 27, 27570 Bremerhaven, Germany

B.H. Buck

Applied Marine Biology, University of Applied Sciences Bremerhaven, An der Karlstadt 8, 27568 Bremerhaven, Germany

R. Langan

School of Marine Science and Ocean Engineering,

University of New Hampshire, Durham, NH 03854, USA

(C) The Author(s) 2017

B.H. Buck and R. Langan (eds.), Aquaculture Perspective of Multi-Use Sites

in the Open Ocean, DOI 10.1007/978-3-319-51159-7_1
} 
constraints on expansion of current methods of production, it is clear that alternative approaches are needed in order for the marine aquaculture sector to make a meaningful contribution to global seafood supply. Farming in offshore marine waters has been identified as one potential option for increasing seafood production and has been a focus of international attention for more than a decade. Though there are technical challenges for farming in the frequently hostile open ocean environment, there is sufficient rationale for pursuing the development of offshore farming. Favorable features of open ocean waters include ample space for expansion, tremendous carrying and assimilative capacity, reduced conflict with many user groups, lower exposure to human sources of pollution, the potential to reduce some of the negative environmental impacts of coastal fish farming (Ryan 2004; Buck 2004; Helsley and Kim 2005; Ward et al. 2006; Langan 2007), and optimal environmental conditions for a wide variety of marine species (Ostrowski and Helsley 2003; Ryan 2004; Howell et al. 2006; Benetti et al. 2006; Langan and Horton 2003). Those features, coupled with advances in farming technology (Fredheim and Langan 2009) would seem to present an excellent opportunity for growth, however, development in offshore waters has been measured. This has been due in large part to the spill over from the opposition to nearshore marine farming and the lack of a regulatory framework for permitting, siting and managing industry development. Without legal access to favorable sites and a "social license" to operate without undue regulatory hardship, it will be difficult for open ocean aquaculture to realize its true potential. Some parallels can be drawn between ocean aquaculture and electricity generation. Continued reliance on traditional methods of production, which for electricity means fossil fuels, is environmentally and economically unsustainable. There is appropriate technology available to both sectors, and most would agree that securing our energy and seafood futures are in the collective national interest. The most advanced and proven renewable sector for ocean power generation is wind turbines, and with substantial offshore wind resources in the, one would think there would be tremendous potential for development of this sector and public support for development. The casual observer might view the ocean as a vast and barren place, with lots of space to put wind turbines and fish farms. However, if we start to map out existing human uses such as shipping lanes, pipelines, cables, LNG terminals, and fishing grounds, and add to that ecological resource areas that require some degree of protection such as whale and turtle migration routes, migratory bird flyways, spawning grounds, and sensitive habitats such as corals, the ocean begins to look like a crowed place. Therefore, when trying to locate new ocean uses, it may be worthwhile to explore possibilities for co-location of facilities, in this case wind turbines and fish and shellfish farms. While some might argue that trying to co-locate two activities that are individually controversial would be a permitting nightmare, general agreement can probably be reached that there are benefits to be gained by reducing the overall footprint of human uses in the ocean. Meeting the challenges of multi-use facilities in the open ocean will require careful analysis and planning; however, the opportunity to co-locate sustainable seafood and renewable energy production facilities is 
intriguing, the concept is consistent with the goals of Marine Spatial Planning and ecosystem based management, and therefore worthy of pursuit.

\subsection{Aquaculture-A Historical Overview}

The transition on land from hunting to agriculture took thousands of years. In the oceans, the transition from capture fishing to modern aquaculture production happened in just two human generations. As late as 1965, a major review did not pay much attention to the potential of aquaculture. Christy and Scott (1965) considered marine farming only in passing for oysters and other mollusks and predicted that increasing use of fresh and brackish ponds in low-income countries might be a means to increase local protein output. By 2009, however, the world's human population consumed more cultured fish than was caught in the wild. Indeed, technological progress has been so rapid that the number of species domesticated for aquaculture now exceeds the number of species domesticated on land (Duarte et al. 2007). Monoculture currently dominates production and a few species, carps, shrimp, prawns, salmon and trout, make up half of total production (Asche et al. 2008). We have long since lost sight of the implications and consequences of culturing the land - but a similar process is now taking place at sea and we hardly notice it. As this is a change similar to the agricultural revolution on land which by archaeologists was identified as the "Neolithic Revolution", in all of these senses we are living through a 'Neolithic' revolution of the oceans.

The fact that aquaculture, for all practical concerns, is a very recent phenomenon may explain many of its characteristics. The industry has experienced almost exponential growth while it has suffered heavily from the spread of diseases in monoculture farms and has been severely impacted and restructured as a result of boom-and-bust growth, particularly around 1990. What was to the first generation of aquaculture entrepreneurs a business of trial-and-error and reliance on the family and local work force is now a globalized corporate enterprise. Science and public management largely saw their roles in the early period as ones of support and encouragement but have now developed agendas of inquiry and management. Major problems such as feed and access to marine space loom large as future threats to the industry. All of these characteristics identify aquaculture as an industry in an early rather than mature phase of growth.

Aquaculture comprises both fresh and brackish water production as well as marine aquaculture (sometimes called mariculture). There is no clear-cut dividing line between working in the different environments, partly because some of the major cultured finfish such as salmon are anadromous, and partly because of learning and innovation across the sectors. Fresh and brackish water aquaculture are characterised by relatively small-scale operations while marine aquaculture is now dominated by larger scale operations. Since the 1980s, marine aquaculture has contributed between 50 and $60 \%$ of global traded production volume with a 


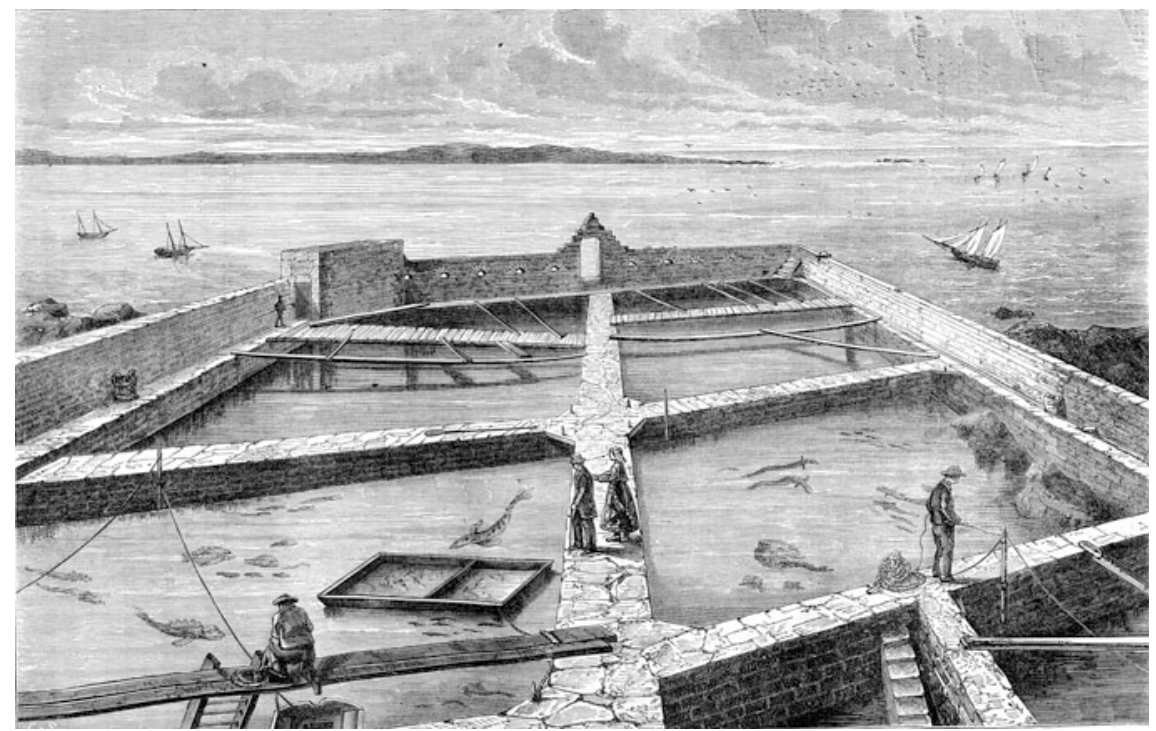

Fig. 1.1 Historical image of an aquaculture farming enclosure (CC 2016)

decreasing trend, while traded value is down from 40 to $32 \%$ in 2013 relative to fresh and brackish species (FAO 2016).

The origins of fish farming may be found far back in time. Freshwater aquaculture emerged at least 3000 years ago in East Asia and the Middle East. Carp in particular became a very important local food source for China and developed significantly in the eighteenth and nineteenth centuries (Li 1997). Similarly, the origins of inshore saltwater aquaculture go far back in time and seem to have originated independently in several regions. Roman towns relied on closed inshore lagoons for the provision of saltwater fish and shellfish at least two millennia ago (McCann 2003). The Polynesian culture of the Hawaiian Islands had developed extensive inshore lagoon fish farming centuries before the arrival of Europeans (Ziegler 2002). Little historical research has been undertaken but it is clear that in Europe, fishponds throughout the pre-modern period were prestigious undertakings, which catered to the needs of affluent consumers who added diversity and freshness to their meals at very high costs (Serjeantson and Woolgar 2006) (Fig. 1.1). The system often depended on collecting and transferring young fish or shellfish to an artificial environment. In Asia, fish farming was organically linked to local aquatic ecosystems such as rice paddies and sewage systems. This extensive fish farming practice was relatively inexpensive and therefore catered to the needs of farmers as well as the elite.

The bottleneck to European fish farming was the development of artificial hatcheries. In Germany, Jacobi (1768) cracked the code to enable external fertilization of brown trout and salmon by extracting and mixing eggs and sperm from mature trout and successfully cultivated the offspring. News of his discovery spread 
slowly and reached the United Kingdom in the 1830s and Norway by 1850 when it led to a short burst of mostly failed experiments (Hovland et al. 2014). This was a time of great expansion of cities and markets. However, this was also a time when oceanic fisheries made great strides forward in the development of trawling and propulsion (Cushing 1988). Steam trawlers soon provided such abundant landings that interest in aquaculture subsided in Europe except for a minor trout industry.

Only in the 1960s did a new and sustained push for aquaculture begin. It came about as a result of independent developments in many regions of the world including Japan, China, the United States, and Europe. The origin of these developments is so far poorly researched with the notable exception of the important Norwegian case (Hovland et al. 2014). Our lack of knowledge is compounded by the fact that the statistical evidence for aquaculture only becomes solid in the 1980s. Nevertheless, it is safe to say that the first major increase took place in Southeast Asia. The expansion built on traditional techniques, but was supported by state policies. The widespread use of explosives and poison in local fisheries had led to a rapid depletion of marine resources. The governments of the Philippines, Indonesia and Thailand saw aquaculture as a means to feed a growing population and as a source of employment for fishermen who were losing their jobs. This local development prepared fish farmers to seize the opportunity when - as a consequence of overfishing - the market for penaeid shrimp soared in Japanese and Western markets around 1970. Over the next twenty years, coastal mangrove forests were cut down to give way for fish and shrimp ponds that were used for extensive practices relying on the natural productivity of the environment. In the mid to late 1980s a new intensive form of cultivation in Southeast Asia gained ground. Intensive farming involves controlling the environment by means of pumps, aerators and generators as well as access to quality feed. Globalisation of markets enabled the injection of capital into an industry that rapidly became dominated by a few large business groups. The giant tiger shrimp (Penaeus monodon) was the most profitable commodity and quickly dominated production (Butcher 2004). With concentration came, however, increased threats from diseases that caused heavy losses to the industry, which responded by injections of antibiotics, salinization of lands and expanding production to new fertile mangrove forests (Zink 2013; Hall 2003). In short, the environmental consequences of this early success of the industry were dire while profits were high.

The rise of aquaculture depended on a concomitant dramatic increase in the availability of feed. In the early 1970s, Peruvian (Glantz 1986) and Danish (Holm et al. 1998) fish reduction operations provided millions of tonnes of fishmeal and fish oil as cheap and efficient feed for agriculture as well as aquaculture. As these pelagic resources proved volatile and vulnerable to overexploitation, the aquaculture industry faced a potentially limiting factor to growth. Despite massive improvements in feed technology and the introduction of vegetable (but omega 3-deficient) protein, the feed problem remains a major challenge both to future growth and public perception (Natale et al. 2013).

Science and technological innovation pointed to a way forward. Aquaculture science developed in the United States in particular, and by 1969 the World 
Mariculture Society was established, renamed in 1986 the World Aquaculture Society or WAS (Avault and Guthrie 1986). Today the WAS has more than 3000 members in about 100 countries. Although the match of science and industry seemed straightforward, the differing aims and measures of success of business and academia have caused friction at times. Perhaps the most staggering example of the success and problems of the marriage is that of Norwegian salmon farming. Local fishermen and craftsmen began experimenting with salmon farming in Norwegian fjords in the late 1960s. When an entrepreneur developed a cheap open net cage in 1970, the industry took off on a staggering growth trajectory. By 1990 the processes of globalisation and capitalisation had created a Norwegian multi-billion dollar industry. The ripple effects of foreign emulation and Norwegian investments created similar large-scale operations in Chile and smaller-size industries in Canada, Scotland and elsewhere. Almost from the beginning, the Norwegian state and industry joined forces to ensure that science matched industry needs. The state provided lucrative land and water licenses for industry and invested heavily in research. Population genetics in particular perfected the cultured salmon species, while epidemiological research was crucial in combating diseases. Scientists became divided, however, in their belief in the sustainability of the industry. The concern became obvious in 2010 when one director of research predicted a tenfold increase of production while the Director of the Department of the Environment advocated a halving of the industry out of concern for wild salmon and the natural environment (Hovland et al. 2014). Such disagreement, based on differing scientific measures and methods, indicates the degree to which aquaculture had rapidly moved from being a productive force to also being a risk.

The rise of aquaculture depended on the willingness of buyers to substitute cultured products for wild fish. While environmental concerns have been voiced by some consumer organisations, the overall picture is one of market acceptance (Natale et al. 2013). The rise in Western per capita demand for fish was associated with the recognition of fish as a health food, including farmed fish, and has enabled a doubling of fish consumption in developed countries since 1950. Local communities have also largely embraced aquaculture as a source of income despite environmental and land issues. A comparative study of the introduction of forestry and aquaculture industries in South East Asia showed that public perception of aquaculture entrepreneurs - including big companies - was positive while forestry companies were resented as intrusions by big capital (Hall 2003). Similarly, the public perception of aquaculture in Chile was a warm welcome because of job creation. The demands on land and water access are now being identified in Norway as a major challenge to the public perception of the industry (Hovland et al. 2014).

While most of the world's aquaculture is still conducted in semi-intensive operations there is no doubt that the direction is towards increased control of production (Asche et al. 2008). Fish farmers have leap-frogged the technological innovation that took millennia on land and use advanced technologies in a marine environment - of which, paradoxically, we have not yet developed a scientific understanding. The expansion of aquaculture has brought about lower fish prices and introduced jobs and income to developing countries as well as to regions in the 
developed world that might otherwise have been depopulated. The industry is, however, highly volatile and subject to major threats such as disease and marine space access. Aquaculture has often been branded as a Blue Revolution akin to the 1970s Green Revolution of agriculture. The comparison is apt in terms of the contribution by the industry to increased food security as production has vastly exceeded population growth and offset the stagnation of capture fish landings. It is also apt in terms of the increased use of medicine, toxins and other technology for the production of natural resources and in terms of species manipulation such as by turning a species like salmon into a semi-vegetarian. Aquaculture may be seen as a true harbinger of the human condition in the Anthropocene-an epoch in which humans have become the main geo-biological agent.

Despite the tremendous growth in aquaculture over the past five decades, seafood demand is projected to outpace supply by 40 million metric tons by 2030 (FAO 2006). With capture fisheries stagnant, and space constraints on continued expansion of nearshore aquaculture, it is clear that alternative means of production are needed. There are two potential means by which marine aquaculture production can expand either land-based recirculating aquaculture systems or development of the technological capacity for farming in exposed oceanic locations. A Canadian study indicated that land based systems are not yet profitable for full grow out of larger fish while they are highly efficient and provide better environmental controls for the production of juvenile fish (Boulet et al. 2010). Recent investments in land-based systems in Europe indicate the potential of cutting transportation costs by locating the industry close to market when energy and water resources are available. Land-based systems may also help alleviate the problem of coastal land access by restricting the use of marine ponds for mature fish. Thus, technological advances in land-based systems have the potential to change the parameters of aquaculture in the future.

\subsection{Moving Aquaculture Operations Offshore}

Farming in offshore marine waters is the other potential option for increasing seafood production and has been a focus of international attention for more than two decades. Though there are technical challenges for farming in the frequently hostile open ocean environment, there is sufficient rationale for pursuing the development of offshore farming. Favorable features of open ocean waters include ample space for expansion, tremendous carrying and assimilative capacity, reduced conflict with many user groups, lower exposure to human sources of pollution, the potential to reduce some of the negative environmental impacts of coastal fish farming, and optimal environmental conditions for a wide variety of marine species, to name a few (Buck 2002, 2004; Ryan 2004; Langan 2007; Langan and Horton 2003; Ostrowski and Helsley 2003; Buck et al. 2004; Helsley and Kim 2005; Benetti et al. 2006; Howell et al. 2006; Ward et al. 2006). A recent study conducted in New Zealand indicated an additional benefit that open ocean locations may be 
subjected to less biofouling (Atalah et al. 2016), a costly maintenance operation for coastal aquaculture. Those features, coupled with advances in farming technology (Fredheim and Langan 2009) would seem to present an excellent opportunity for growth, however, development in offshore waters has been limited. The reasons for this vary depending on location, but include risk aversion, lack of access to capital, clear identification of ownership, and unresolved technological issues (Langan 2012). In some countries, like the USA and some EU member states, lack of a regulatory structure for permitting offshore farms has been an impediment (e.g. Cicin-Sain et al. 2001; Buck et al. 2003), as well as opposition form environmental NGOs (Langan 2012).

Similar to the recent developments in aquaculture, the energy sector has undergone significant changes. Over the course of the last decade, the establishment of offshore wind farms as a sustainable and economically viable form of energy production has generated interest in the potential for optimizing use of offshore sites to include other activities. Thus, consideration of multiple uses of offshore renewable energy systems in the design phase so that the economic benefits from a unit area of sea can be maximized in a sustainable way has been a central research topic since the year 2000 (Buck 2001).

\subsection{The Multi-use Concept}

One particular area of interest is combining energy and aquaculture-based seafood production within the same ocean footprint (Buck and Krause 2012, 2013). Interest in marine aquaculture in exposed oceanic locations has been explored as a standalone activity, however, commercial development has been thus far very limited. The stability of offshore energy production structures (e.g. wind turbine and oil drilling platforms) is an attractive feature for a suite of requirements for aquaculture production, including attachment points for mooring cages and longlines, and for mounting feeding, hatchery and nursery systems. Though desirable attributes for energy and seafood production may not exist at all offshore sites, there is likely a subset of locations that are suitable, acceptable and economically viable. Thus, the slogan "Maximizing the benefit of a piece of land" (Buck 2009a) is a potential solution to foster offshore multi-use concepts of renewable energy systems, but also from any other offshore installation type, such as other renewable energy installations (e.g. tidal energy) or oil and gas (Kaiser et al. 2011).

\subsubsection{Pilot Projects in Russia}

The first synergy of offshore platforms with aquaculture was initiated in the Caspian Sea (27 km off the Turkmenian shore) in 1987 (Fig. 1.2a-d), where a fish farm was moored next to an oil rig (Bugrov 2016). Unfortunately, high operating costs led to 

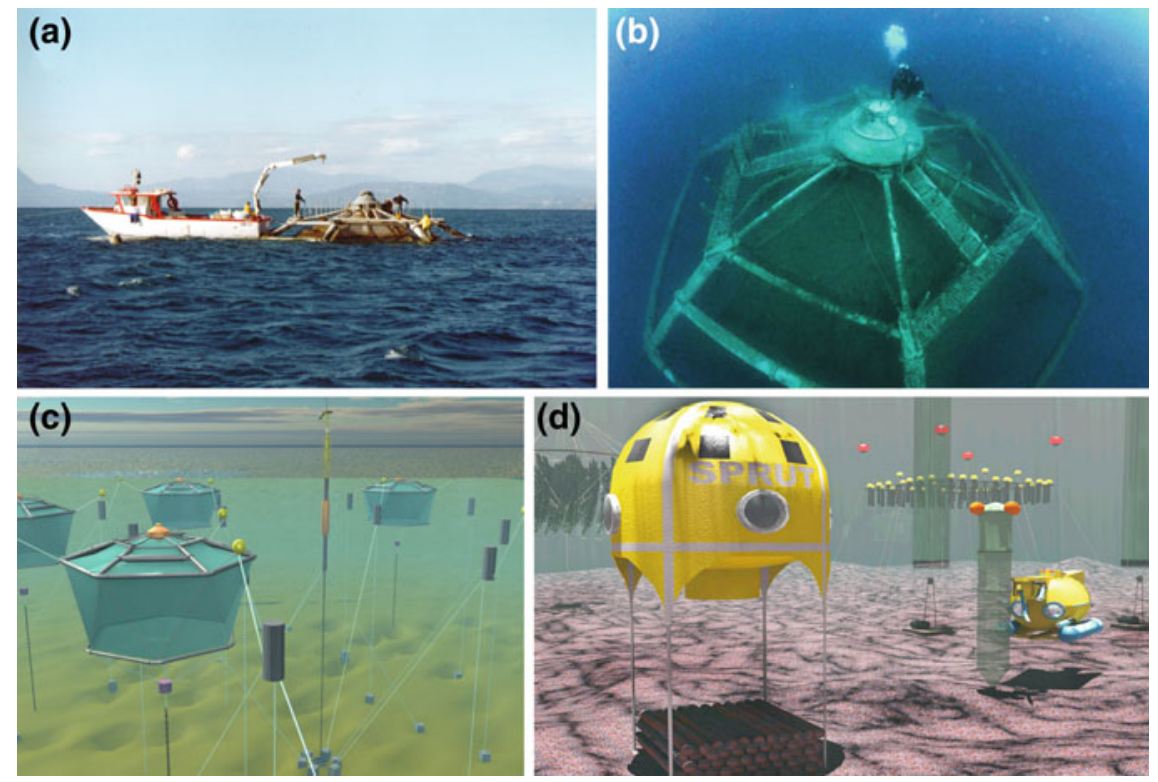

Fig. 1.2 Submersible cage complex "Sadco-Kitezh" (consisting of 6 individual cage modules) disposed next to an offshore oil-rig in the Caspian Sea in 1988, floating (a) and submerged (b); c displays a concept for a series of submerged cages and $\mathbf{d}$ shows a collection of submergible devices for fish and bivalves and floating seaweed a test site following an IMTA-concept (Bugrov 2016 following Buck et al. 2004)

a shutdown of this enterprise at a very early stage (Bugrov 1992, 1996). Over the past 25 years more than 1000 oil and gas structures were installed in the same area and more than 300 in the Black Sea. The amount of time to decommission these platforms takes on average of one year and international experience in disassembling those platforms showed that the average cost of disassembly works is several million Euros (Bugrov 1991). Resigning the dismantling of the platforms and therefore saving costs could support a cross-subsidasation of aquaculture. This would have had an influence on the commercial potential of these multi-use concept, however, that was not taken into account at that time.

\subsubsection{Pilot Projects in the USA}

In the Gulf of Mexico the cumulative costs of a total removal of oil rigs had reached an estimated \$1 billion by the year 2000 (Dauterive 2000). In this respect the search for a way of conversion of such structures became more important and initiated the search for alternatives. Operators have recognized that during a rig's productive years, significant marine life aggregates on and around its structures. This is also 
caused by the fact that marine areas occupied by offshore platforms are off limits for commercial fishing vessels due to safety reasons (Berkenhagen et al. 2010). This results in an increase in biomass of fish or other species and/or a greater number of species in this area aggregating at the artificial reefs. These areas then can be considered as more or less a marine protected area (MPA). Marine scientists have therefore suggested preserving much of this marine life and encouraging further natural productivity (Jensen et al. 2000). While the operator benefits by avoiding the substantial cost of removal, populations of marine species benefit from the refuge the structures provide. These findings encouraged recreational fisherman, divers, offshore oil and gas operators, aquaculturists and others who could benefit from the increased density to establish the "Rigs-to-Reefs" program in American and European Seas (Reggio 1987), where decommissioned offshore oil and gas rigs were turned into artificial reefs. Since then many scientists have reported that these artificial reefs increase the number and diversity of marine organisms adjacent to these sites (e.g. Bohnsack et al. 1994; Zalmon et al. 2002) including many commercially important fish, shellfish and crustacean species (Bohnsack et al. 1991; Jensen et al. 2000).

To this point, some efforts have been carried out to successfully install offshore aquaculture constructions as pilot systems even in the open Pacific but none have so far reached a continuous commercial operation. In particular, projects carried out in the USA were of prime importance for the successful installation of various offshore systems (e.g. Loverich 1997, 1998; Loverich and Gace 1997; Braginton-Smith and Messier 1998; Loverich and Forster 2000). These efforts led to the idea to include various disused oil platforms in the Gulf of Mexico in a multi-use concept (Miget 1994; Wilson and Stanley 1998) (Fig. 1.3a-b).

The National Sea Grant College Program funded such research projects to explore offshore sites for stand-alone mariculture purposes. The Open Ocean Aquaculture Program at the University of New Hampshire is one of the few attempts made so far (Ward et al. 2001) as well as the Hawaiian Offshore Aquaculture Research Project (HOARP) (Ostrowski and Helsley 2003). Due to the
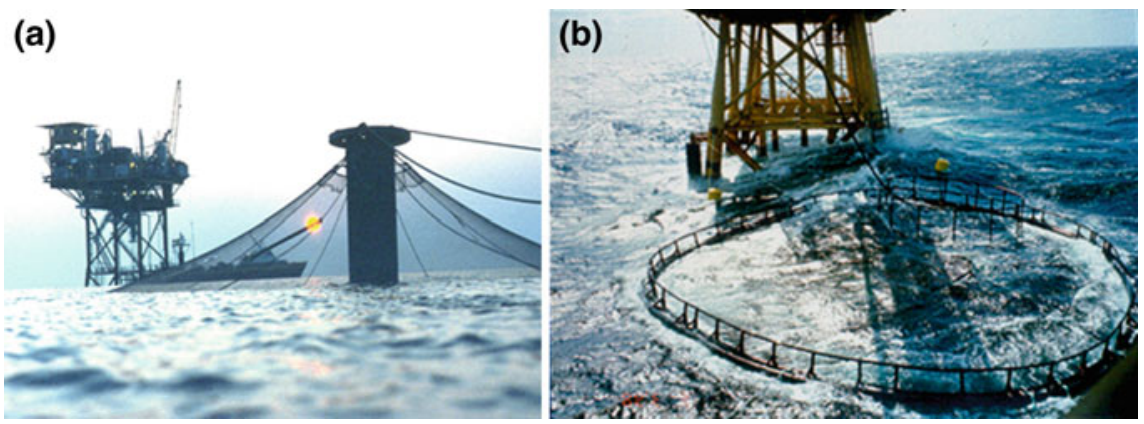

Fig. 1.3 a Ocean Spar Cage deployed next to an offshore oil rig in federal waters 22 miles off Mississippi in the Gulf of Mexico (Bridger 2004); b typical 4-5 m winter seas moving through the cage and platform site 
technological capacity of the US and their extended marine areas, the movement of aquaculture activities into offshore areas gained momentum for a period of time (Dalton 2004) and has encouraged other western countries to follow.

Several studies have estimated that tons to tens of tons of wild fish congregate in the immediate area around fish farms in both warm and cold-temperate environments (Dempster et al. 2004, 2009; Leonard et al. 2011). For some species, artificial reefs can increase the availability of critical habitat (Polovina and Sakai 1989) for feeding, spawning, and juvenile refugia (Jensen et al. 2000) in addition to reducing the detrimental impacts on existing habitats by mobile gear exclusion (Claudet and Pelletier 2004). Additionally, these constructions can be helpful in developing cost effective fishing practices by reducing displacement cost for the inshore fleets and reducing competition for territory between fishermen. The question whether artificial reefs close to aquaculture sites would decrease the impact of cultured fish waste on the surrounding ecosystem has been suggested as a topic of research (Buschmann et al. 2008).

\subsubsection{Pilot Projects in Germany}

In Germany, the plans for the massive expansion of wind farms in offshore areas of the North Sea triggered the idea of a combination of wind turbines with other uses. Various multi-use concepts were followed led by tourism, marine protected areas (MPAs), passive fishery actions as well as desalination and research, just to name a few (see Fig. 1.4). Another concept is to co-use wind farm installations with extensive aquaculture of native bivalves and macroalgae (e.g. Buck 2002, 2004; Buck and Buchholz 2004; Buck et al. 2008, 2012; Lacroix and Pioch 2011). Due to the fact that offshore wind farms provide an appropriately sized area free of commercial shipping traffic (as most offshore wind farms are designed as restricted-access areas due to hazard mitigation concerns), projects on open ocean aquaculture have been carried out since 2000 in the German Bight (Buck 2001). Further expansion towards finfish culture has since then been proposed and carried out in land-based facilities with regard to system design and coupling technologies for submersible fish cages as well as Integrated Multi-trophic Aquaculture (IMTA) and site-selection.

The combination of wind energy and aquaculture enterprises was already proven in China in the early 1990s (Chunrong et al. 1994), however, these wind turbines were land-based and used to enhance dissolved oxygen in the water column as well as to increase fishpond temperature. Today, many other research institutes have adopted this concept and have conducted feasibility studies within their coastal and EEZ waters, in Denmark, The Netherlands, Belgium, the UK, USA and others (Figs. 1.4 and 1.5; Wever et al. 2015). 


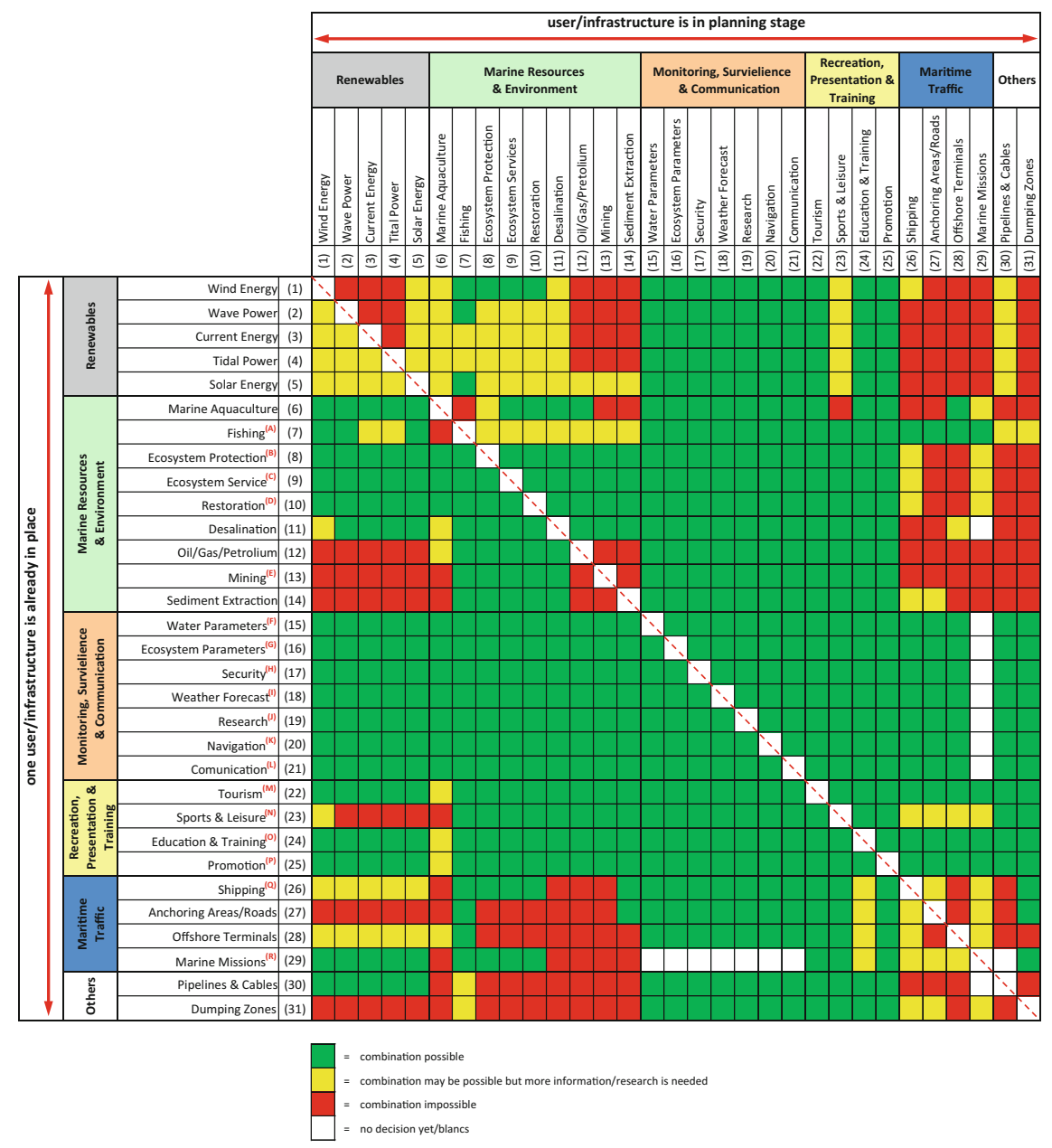

Fig. 1.4 Assessment of potential uses and achievable multi-use options for users/installations, which are already at sea, and for those, which are currently in planning phase. $A$ includes traditional fishing techniques without seabed connection (due to avoid any contact to ground cables/pipes) as well as sustainable/passive and recreational fishing; $B$ includes MPA's, nature conservation, compensatory measures; $C$ including e.g. buffer zones, nutrient cycling, primary production, etc.; $D$ includes e.g. shellfish or seaweed restoration and rehabilitation; $E$ includes e.g. manganese/copper/cobalt and others; $F$ includes the monitoring of oceanographic parameters (salinity, $\mathrm{pH}$, temperature, $\mathrm{O}_{2}$, etc.), chemical parameters (nitrite, nitrate, phosphate, etc.), as well as harmful substances (toxins, heavy metals, etc.); $G$ includes mapping of flora and fauna, other habitat parameters; $H$ includes the surveillance of the national/EEZ territory (traffic of drugs or other illegal goods, illegal passage of persons and equipment, etc.), as well as security on the entire traffic (commercial and recreational); I includes also tsunami watch; $J$ includes marine/coastal research on moving platforms (vessels, buoys, etc.) and fixed platforms (research stations); $K$ includes e.g. radar; $L$ includes telephone and network cables as well as wireless systems; $M$ includes sport fishing, diving, daily visiting tourists with interacting interests, etc.; $N$ includes e.g. sailing regatta, races, etc.; $O$ includes security training for work at platforms/vessels for the offshore industry or to teach students; $P$ includes preparation of advertising films, movies; $Q$ includes commercial as well as recreational shipping; $R$ includes marine practice areas, firing and torpedo areas as well as submarine areas (Modified after Buck (2013), images by AWI/Prof. Dr. Bela H. Buck) 


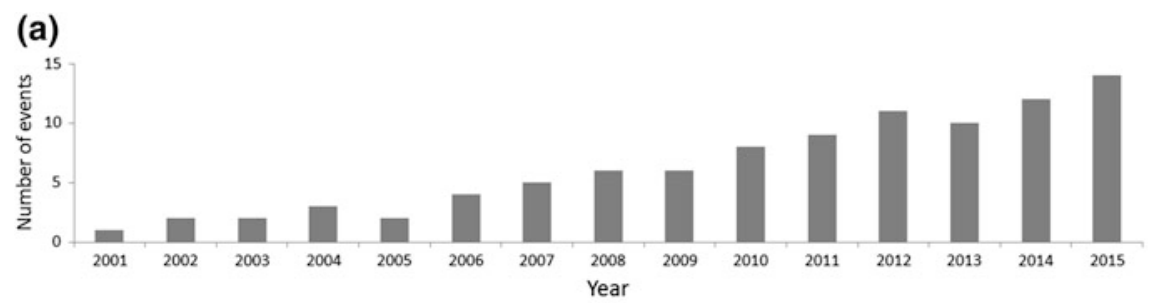

(b)

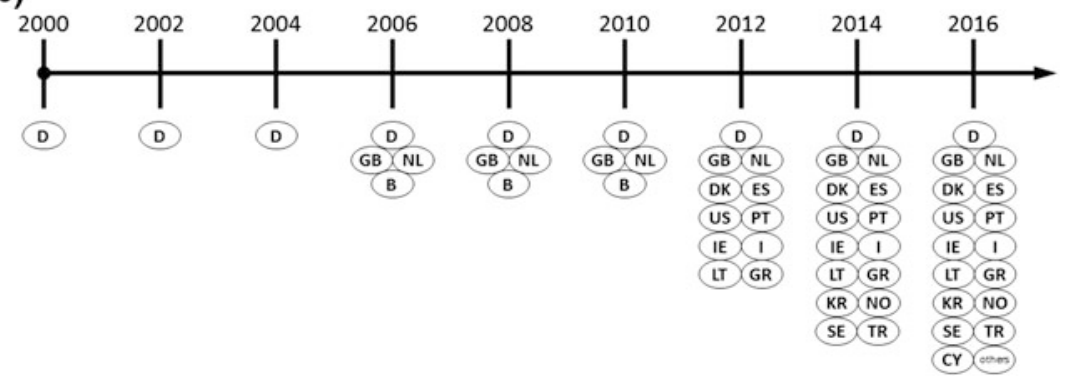

Fig. 1.5 a Graph shows a time scale with the number of events worldwide in which the combination of aquaculture within offshore wind farms was discussed; $\mathbf{b}$ countries involved in aquaculture wind farm combinations on a time line. Both images modified after Wever et al. 2015

\subsection{Initiation to the Topic}

For this rather risky and expensive development to happen in practical terms, an understanding of basic needs, such as design requirements, data acquisition, site specifications, operation and maintenance issues, etc. is required. Offshore structures will need to be modified or adapted to accommodate other uses without compromising functionality and safety. Indeed, this move further from shore and into higher energy open ocean environments has created demand for new vessels for installation, operation, maintenance and decommissioning. While it is clear that multi-uses will require multiple types of service vessels, there will be areas of overlap where economies of scale can be achieved, for example in the transport of technicians. Technologies for aquaculture in exposed environments are still in the early stages of development, and combined use at energy production sites will require some rethinking of engineering design.

Other combinations of offshore uses are possible, thus supporting the trend to combine expensive infrastructure and collocate it in offshore areas (Buck 2009b). In this respect a great deal of discussion has begun on moving various kinds of uses to regions where more space is available, focusing specifically on resources, which could become scarce in the near future (e.g. production of food). However, one has to keep in mind that plausibility and profitability are incontrovertible constraints to any enterprise offshore, especially when combining them into a multi-use concept. Some concepts to move industrial interests off the coast did not fulfil these 

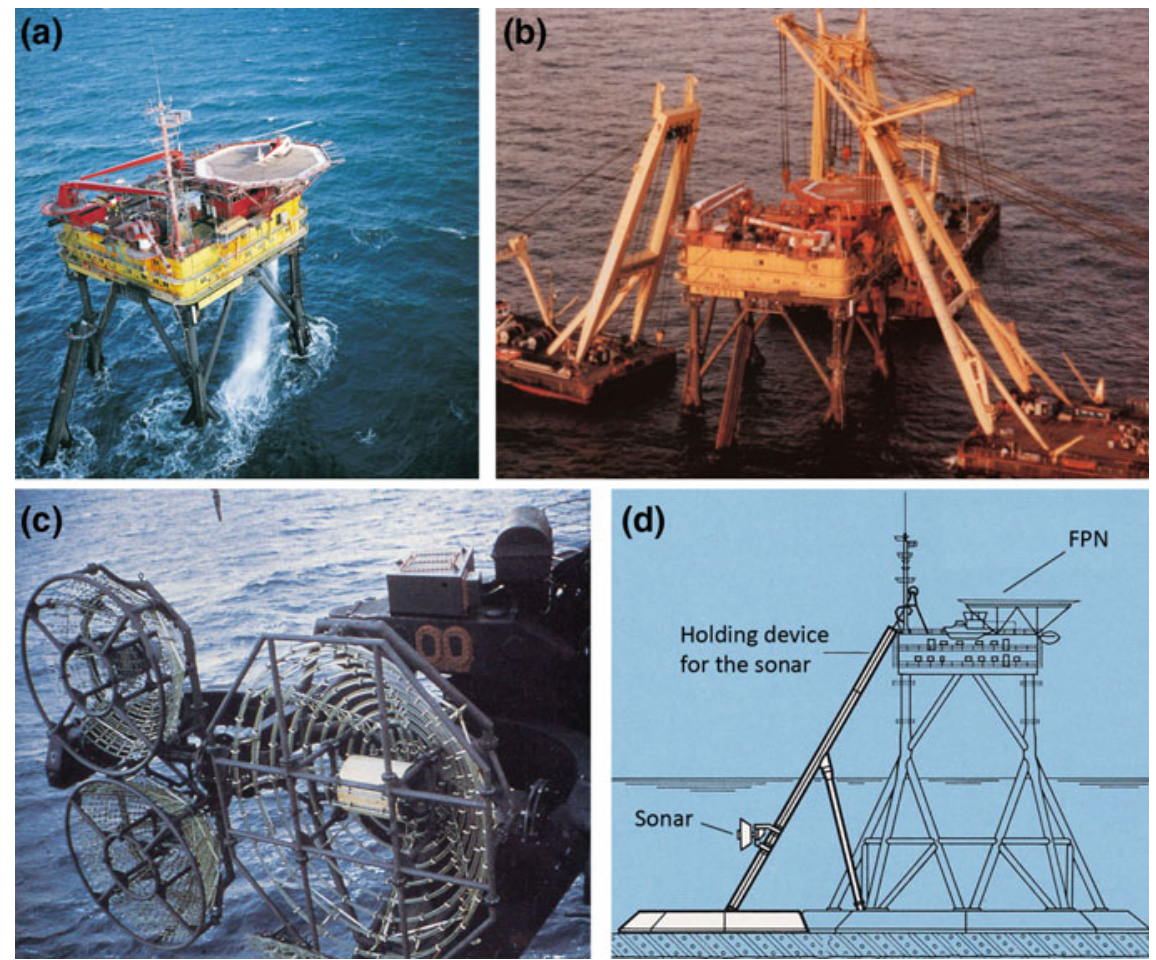

Fig. 1.6 a Research platform "Nordsee" (FPN) about $75 \mathrm{~km}$ off the German mainland; b dismantling of the platform 20 years later; c sonar research device from the Federal Office of Defense and Procurement (BWB) before positioning at the basement of the foundation; $\mathbf{d}$ drawing of the sonar research device. All images modified after IMS 2016

requirements. For instance, the ChevronTexaco Corp plan to construct a US\$650 million offshore liquefied natural gas receiving and re-gasification terminal with accommodation for personnel (to be located $13 \mathrm{~km}$ off the coast of Baja California, Mexico) (ChevronTexaco 2003) could not be realized as originally conceived due to escalating costs. The Forschungsplattform Nordsee (FPN, Research Platform "North Sea"), which was constructed for 35 million DM ${ }^{1}$ in 1974 about $75 \mathrm{~km} \mathrm{NW}$ off the Island of Helgoland (Germany) housed 14-25 people, a helicopter landing site as well as a jetty (Fig. 1.6a-d), and were equipped for a number of different functions, including marine ecology, oceanography, and climate research by natural scientists, underwater technology and sensors by engineers as well as defence technology by the former Federal Office of Defence and Procurement (BWB). However, even this met, over the course of time, a similar fate. The platform was dismantled in 1993 due to high maintenance and operational costs (Dolezalek 1992).

\footnotetext{
${ }^{1} \mathrm{DM}=$ Former German currency, $1 \mathrm{DM} \approx 0.5 €$.
} 
Hundreds of offshore future visions, such as the concepts for space, land and sea of Agence Jacques Rougerie Architecte (Rougerie 2012) or the carbon-neutral self-sufficient offshore farming platform, called Equinox (FDG 2011), exist on paper, but are yet far away from practical realization. Other uses that could have an economic potential but have not been realized so far are passive fishing in combination with other uses in the open ocean. Furthermore, there is strong interest in the production of freshwater off the coast in areas with a significant lack of freshwater supply (He et al. 2010). Although there has been plenty of research into the use of renewable energy to power the desalination process (Carta et al. 2003; Forstmeier et al. 2007; Heijman et al. 2010) no offshore demonstration has been carried out so far.

This book pulls the different strands of investigations in this new emerging field together and provides an overview of the current state-of-the-art of the research fields involved. Out of an array of different possible offshore renewable energy systems, offshore wind farms are most advanced in practical terms. Thus, the expertise focuses strong on these systems and its potential link with offshore aquaculture. The suitability of aquaculture production together with or at offshore wind energy sites will be discussed in detail.

\section{References}

Asche, F., Roll, K. H., \& Tveterås, S. (2008). Future trends in aquaculture: Productivity growth and increased production. In: M. Holmer, K. Black, C. M. Duarte, N. Marba \& I. Karakassis (Eds.), Aquaculture in the ecosystem (pp. 271-92). Berlin: Springer.

Atalah, J., Fletcher, L. M., Hopkins, G. A., Heasman, K., Woods, C. M. C., \& Forrest, B. M. (2016). Preliminary assessment of biofouling on offshore mussel farms. Journal of the World Aquaculture Society.

Avault, J. W., \& Guthrie, P. W. (1986). The formation and history of the world mariculture society, 1969-1986. Journal of the World Aquaculture Society, 17, 64-71.

Benetti, D., O'Hanlon, B., Brand, L., Orhun, R., Zink, I., Doulliet, P., Collins, J., Maxey, C., Danylchuk, A., Alston, D., \& Cabarcas, A. (2006). Hatchery, on growing technology and environmental monitoring of open ocean aquaculture of cobia (Rachycentron canadum) in the Caribbean. World Aquaculture Society, Abstract. In Proceedings of Aquaculture 2006, Florence Italy.

Berkenhagen, J., Doring, R., Fock, H., Kloppmann, M., Pedersen, S. A., \& Schulze, T. (2010). Conflicts about spatial use between wind farms and fisheries-What is not implemented in marine spatial planning. Inf. Fischereiforsch., 57, 23-26.

Bohnsack, D. E., McCellan, D. B., \& Hulsbeck, M. (1994). Effects of reef size on colonization and assemblage structure of fishes at artificial reefs off Southeastern Florida. Mar. Sci., 55, 796-823.

Bohnsack, J. A., Johnson, D. L., \& Ambrose, R. E. (1991). Ecology of artificial reef habitats and fishes. In W. Seaman \& L. M. Sprague (Eds.), Artificial habitats for marine and freshwater fisheries (pp. 61-108). Cambridge, MA, USA: Academic Press.

Boulet, D., Struthers, A., \& Gilbert, E. (2010). Feasibility study of closed-containment options for the British Columbia aquaculture industry, Retrieved June 12, 2016, from http://publications. gc.ca/pub?id=9.694792\&sl=0 
Braginton-Smith, B., \& Messier, R. H. (1998). Design concepts for integration of open ocean aquaculture and Osprey ${ }^{\mathrm{TM}}$ Technology. In W. H. Howell, B. J. Keller, P. K. Park, J. P. McVey, K. Takayanagi \& Y. Uekita (Eds.), Nutrition and Technical Development of Aquaculture, Proceedings of the Twenty-Sixth U.S.-Japan Aquaculture Symposium, Durham/New Hampshire/USA, September 16-18, 1997 (pp. 239-245). UJNR Technical Report No. 26, Durham, University of New Hampshire Sea Grant Program.

Bridger, C. J. (Ed.) (2004). Efforts to develop a responsible offshore aquaculture industry in the Gulf of Mexico: A compendium of offshore aquaculture consortium research. MASGP-04-029. Mississippi-Alabama Sea Grant Consortium, Ocean Springs, MS.

Buck, B. H. (2001). Combined utilization of wind farming and mariculture in the North Sea. Alfred-Wegener-Institute for Polar and Marine Research, 2000-2001 Report: 33-39.

Buck, B. H. (2002). Open Ocean Aquaculture und Offshore-Windparks: Eine Machbarkeitsstudie über die multifunktionale Nutzung von Offshore-Windparks und Offshore-Marikultur im Raum Nordsee. Reports on Polar and marine research. Bremerhaven: Alfred Wegener Institute for Polar and Marine Research, pp. 412-252.

Buck, B. H. (2004). Farming in a high energy environment: potentials and constraints of sustainable offshore aquaculture in the German Bight (North Sea). Germany: Dissertation. University of Bremen.

Buck, B. H. (2009a). Meeting the quest for spatial efficiency: Progress and prospects of extensive aquaculture within offshore wind farms in Europe. The Ecology of Marine Wind Farms: Perspectives on Impact Mitigation, Siting, and Future Uses. Keynote Speaker, 8th Annual Ronald C. Baird Sea Grant Science Symposium, November 2-4, 2009, Newport, Rhode Island (USA).

Buck, B. H. (2009b). Seaweed aquaculture in the open coastal waters, aquaculture and food. Special edition, 4, 100-103.

Buck, B. H. (2013). Upscaling aquaculture operations in offshore environments - challenges and possibilities in Europe. Submariner-Conference - Innovative uses of Baltic marine resources in the light of the EU Blue Growth initiative. 5-6, September 2013, Gdansk (Poland).

Buck, B. H., \& Buchholz, C. M. (2004). The offshore-ring: A new system design for the open ocean aquaculture of macroalgae. Journal of Applied Phycology, 16, 355-368.

Buck, B. H., \& Krause, G. (2013). Short expertise on the potential combination of aquaculture with marine-based renewable energy systems. SeaKult-Sustainable Futures in the Marine Realm. Expertise für das WBGU-Hauptgutachten "Welt im Wandel: Menschheitserbe Meer". Wissenschaftlicher Beirat der Bundesregierung Globale Umweltveränderungen (WBGU).

Buck, B. H., \& Krause, G. (2012). Integration of aquaculture and renewable energy systems, In R. A. Meyers (Ed.), Encyclopaedia of sustainability science and technology (Vol. 1). Springer Science+Business Media LLC. Chapter No. 180, pp. 511-533.

Buck, B. H., Krause, G., Rosenthal, H., \& Smetacek, V. (2003). Aquaculture and environmental regulations: The German situation within the North Sea. In: A. Kirchner (Ed.), International marine environmental law: institutions, implementation and innovation, vol. 64. The Hague: International Environmental. Law and Policies Series of Kluwer Law International.

Buck, B. H., Krause, G., \& Rosenthal, H. (2004). Extensive open ocean aquaculture development within wind farms in Germany: The prospect of offshore co-management and legal constraints. Ocean and Coastal Management, 47, 95-122.

Buck, B. H., Krause, G., Michler-Cieluch, T., Brenner, M., Buchholz, C. M., Busch, J. A., et al. (2008). Meeting the quest for spatial efficiency: Progress and prospects of extensive aquaculture within offshore wind farms. Helgoland Marine Research, 62, 269-281.

Buck, B. H., Dubois, J., Ebeling, M. W., Franz, B., Goseberg, N., Hundt, M., et al. (2012). Mulitple Nutzung und Co-Management von Offshore-Strukturen: Marine Aquakultur und Offshore-Windparks. Open Ocean Multi-Use (OOMU)-Projektbericht, gefördert durch das Bundesministerium für Umwelt, Naturschutz und Reaktorsicherheit.

Bugrov, L. (1991). Alternative using of petroleum-gas structures in the caspian and the black seas for fish-farming and fishing. In 5th International Conference on Aquatic Habitat Enhancement (Artificial Habitats for Fisheries), Long Beach, California, USA. 
Bugrov, L. (1992). Rainbow trout culture in submersible cages near offshore oil platforms. Aquaculture, 100, 169.

Bugrov, L. (1996). Underwater fish-farming technology for open sea areas: Review of a 10-year experience. In Open Ocean Aquaculture (pp. 269-296). Portland, Maine: UNHMP-CPSG-96-9. Sea Grant College Program.

Bugrov, L. (2016). Personal communication and provision of images. Saint Petersburg, Russia: State Research Institute on Lake and River Fisheries.

Buschmann, A. H., Hernández-González, M. C., Aranda, C., Chopin, T., Neori, N., Halling, C., \& Troell, M. (2008). Mariculture waste management. In S. E. Jørgensen \& B. D. Fath (Ed.), Ecological engineering. Vol. 3 of encyclopedia of ecology (pp. 2211-2217). Oxford: Elsevier.

Butcher, D. (2004). The closing of the frontier. A history of the marine fisheries of Southeast Asia c. 1850-2000. Singapore: ISEAS/KITLV.

Carta, J. A., Gonzalez, J., \& Subiela, V. (2003). Operational analysis of an innovative wind powered reverse osmosis system installed in the Canary Islands. Solar Energy, 75, 153-168.

CC. (2016). Custodian Consultancy Ltd., 1B Damastown Way, Mulhuddart, Dublin 15, D15 NNOF.

ChevronTexaco. (2003). ChevronTexaco plans offshore LNG terminal. Filtration Industry Analyst, 12, 3.

Chunrong, W., Liangjie, D., Guoxi, L., \& Yuxian, X. (1994). Utilizing wind energy to develop aquaculture industry. In L. Nan, G. Best, C. C. de Carvalho Neto, (Eds.), Integrated energy systems in China-The cold Northeastern region experience. Rome: Food and Agriculture Organisation of the United Nations.

Cicin-Sain, B., Bunsick, S. M., DeVoe, R., Eichenberg, T., Ewart, J., Halvorson, H., et al. (2001). Development of a policy framework for offshore marine aquaculture in the 3-200 Mile U.S. Ocean Zone. Report of the Centre for the Study of Marine Policy, University of Delaware.

Claudet, J., \& Pelletier, D. (2004). Marine protected areas and artificial reefs: A review of the interactions between management and scientific studies. Aquatic Living Resource, 17, 129-138.

Cushing, D. H. (1988). The provident sea. Camebridge: Camebridge University Press.

Christy, F. T., \& Scott, A. (1965). The common wealth in ocean fisheries. Some problems of growth and economic allocation. Baltimore: Johns Hopkins U.P.

Dalton, R. (2004). Fishing for trouble. Nature, 431, 502-504.

Dauterive, L. (2000). Rigs-to-reef policy, progress, and perspective. OCS Report (U.S. Department of the Interior), pp. 1-12.

Dempster, T., Sanchez-Jerez, P., Bayle-Sempere, J. T., \& Kingsford, M. J. (2004). Extensive aggregations of wild fish at coastal sea-cage fish farms. Hydrobiologia, 525, 245-248.

Dempster, T., Uglem, I., Sanchez-Peres, P., Fernandez-Jover, D., Bayle-Sempere, J., Neilsen, R., et al. (2009). An ecosystem effect of salmonid farming: Extensive and persistent aggregations of wild fish. Marine Ecology Progress Series, 385, 1-14.

Dolezalek, H. (1992). Oceanographic research towers in European waters. ONR Europe Reports. Office of Naval Research European Office 92-7-R.

Duarte, C. M., Marbà, N., \& Holmer, M. (2007). Rapid domestication of marine species. Science, $316,382-383$.

FAO. (2016). Food and agriculture statistics service, fisheries and aquaculture department. Rome: Food and Agriculture Organization of the United Nations (Accessed June 24, 2016).

FAO. (2006). FAO-fisheries technical paper. No. 500. State of world aquaculture 2006. Rome: Food and Agriculture Organization of the United Nations.

FDG. (2011). Equinox - A carbon-neutral self-sufficient offshore farming platform. Retrieved June 15, 2016 from http://www.formationdesign.com

Forstmeier, M., Mannerheim, F., D’Amato, F., Shah, M., Liu, Y., Baldea, M., et al. (2007). Feasibility study on wind-powered desalination. Desalination, 203, 463-470.

Fredheim, A., \& Langan, R. (2009). Advances in technology for offshore and open ocean aquaculture. In G. Burnell \& G. Allen (Eds.), New technologies in aquaculture: Improving 
production efficiency, quality and environmental management (pp. 914-942). Cambridge, UK: Woodhead Publications.

Glantz, M. H. (1986). Man, state, and fisheries: An inquiry into some societal constraints that affect fisheries management. Ocean Development and International Law, 17, 191-270.

Hall, D. (2003). The international political ecology of industrial shrimp aquaculture and industrial plantation forestry in Southeast Asia. Journal of Southeast Asian Studies, 34, 251-264.

He, X., Li, C., \& Gu, W. (2010). Research on an innovative large-scale offshore wind power seawater desalination system. In World Non-Grid-Connected Wind Power and Energy Conference (WNWEC).

Helsley, C. E., \& Kim, J. K. (2005). Mixing downstream of a submerged fish cage: A numerical study. IEEE Journal of Oceanic Engineering, 30, 12-19.

Heijman, S. G., Rabinovitch, E., Bos, F., Olthoff, N., \& van Dijk, J. C. (2010). Sustainable seawater desalination: Stand-alone small scale windmill and reverse osmosis system. Desalination, 248, 114-117.

Holm, P., Byskov, S., \& Toft-Hansen, S. (1998). Proteiner fra havet: Fiskemelsindustrien $i$ Esbjerg, 1948-1998. Esbjerg: Fiskeri- og Søfartsmuseet.

Howell, W. H., Watson, W. H., \& Chambers, M. D. (2006). Offshore production of cod, haddock and halibut. CINEMar/Open Ocean Aquaculture Annual Progress Report for the Period from January 01-31, 2005. Final Report for NOAA Grant No. NA16RP1718, interim Progress Report for NOAA Grant No. NA04OAR4600155.

Hovland, E., et al. (2014). Norges Fiskeri- og Kysthistorie V. Fagbokforlaget: Bergen.

IMS. (2016). IMS ingenieurgesellschaft mbH, Hamburg.

Jacobi, S. L. (1768). Von der künstlichen Erzeugung der Forellen und Lachse. Lippische Intelligenzblätter, pp. 697-704; 709-720. Retreived May 12, 2016, from http://s2w.hbz-nrw. de/llb/periodical/pageview/124064

Jensen, A., Collins, K. J., \& Lockwood, A. P. (2000). Artificial reefs in European seas. Dordrecht: Kluwer Academic Publishers.

Kaiser, M. J., Snyder, B., \& Yu, Y. (2011). A review of the feasibility, costs, and benefits of platform-based open ocean aquaculture in the Gulf of Mexico. Ocean and Coastal Management, 54, 721-730.

Lacroix, D., \& Pioch, S. (2011). The multi-use in wind farm projects: more conflicts or a win-win opportunity? Aquatic Living Resources, 24, 129-135.

Langan, R., \& Horton, C. F. (2003). Design, operation and economics of submerged longline mussel culture in the open ocean. Bulletin of the Aquaculture Association of Canada, 103, 11-20.

Langan, R. (2007). Results of environmental monitoring at an experimental offshore farm in the Gulf of Maine: Environmental conditions after seven years of multi-species farming. In: C. S. Lee \& P. J. O’Bryen (Eds.), Open ocean aquaculture-Moving forward (pp. 57-60). Oceanic Institute.

Langan, R. (2012). Ocean cage culture. In J. H. Tidwell (Ed.), Aquaculture production systems. Oxford, UK: Wiley-Blackwell.

Leonhard, S. B., Stenberg, C., \& Støttrup, J. (2011). Effect of the horns rev 1 offshore wind farm on fish communities. Follow-up seven years after construction. DTU Aqua, Orbicon, DHI, NaturFocus. Report commissioned by The Environmental Group through contract with Vattenfall Vindkraft A/S.

$\mathrm{Li}$, B. (1997). Agricultural development in Jiangnan, 1620-1850, studies on the Chinese Economy. London: St. Martin's Press.

Loverich, G. F. (1997). A summary of the case against the use of gravity cages in the sea farming industry. Nr. 091997.

Loverich, G. F. (1998). Recent practical experiences with ocean Spar ${ }^{\mathrm{R}}$ offshore sea cages. In R. R. Stickney (Ed.), Joining forces with industry-open ocean aquaculture (pp. 78-79). 
Proceedings of the 3rd Annual International Conference, May 10-15, Corpus Christi, Texas. TAMU-SG-99-103, Corpus Christi, Texas Sea Grant College Program.

Loverich, G. F., \& Gace, L. (1997). The effect of currents and waves on several classes of offshore sea cages. In C. Hesley (Ed.), Open ocean aquaculture: chartering the future of ocean farming (pp. 131-144). Proceedings of an International Conference, April 23-25, 1997, Maui, Hawaii. UNIHI-Seagrant-CP-98-08, Maui, University of Hawaii Sea Grant College Program.

Loverich, G. F., \& Forster, J. (2000). Advances in offshore cage design using spar buoys. Marine Technology Society Journal, 34, 18-28.

McCann, M. (2003). The Roman port and fishery of Cosa. Rome: American Academy. in Rome.

Miget, R. J. (1994). The development of marine fish cage culture in association with offshore oil rigs. In K. L. Main \& C. Rosenfeld (Eds.), Culture of high value marine fishes in Asia and the United States (pp. 241-248). Proceedings of a Workshop in Honolulu, Hawaii, August 8-12, 1994. The Oceanic Institute.

Natale, F., Hofherr, J., Fiore, G., \& Virtanen, J. (2013). Interactions between aquaculture and fisheries. Marine Policy, 38, 205-213.

Ostrowski, A. C., \& Helsley, C. E. (2003). The Hawaii offshore aquaculture research project: Critical research and development issues for commercialization. In: C. J. Bridger \& B. A. Costa-Pierce (Eds.), Open ocean aquaculture: From research to commercial reality (pp. 119-128). Baton Rouge, Louisiana, USA: The World Aquaculture Society.

Polovina, J. J., \& Sakai, I. (1989). Impacts of artificial reefs on fishery production in Shimamaki. Japan Marine Science, 44, 997-1003.

Reggio, V. C. (1987). Rigs-to-reefs: The use of obsolete petroleum structures as artificial reefs. OCS Report MMS 87-0015. New Orleans, U.S. Department of the Interior, Minerals Management Service, Gulf of Mexico OCS Region.

Rougerie (2012) Agence Jacques Rougerie Architecte, Péniche Saint Paul, Port des Champs-Elysées 75008 Paris. Retrieved June 2, 2016, from http://www.rougerie.com/12.html

Ryan, J. (2004). Farming the deep blue. Bord Iascaigh Mhara Technical Report. Dublin, Ireland: BIM.

Serjeantson, D., \& Woolgar, C. M. (2006). Fish consumption in medieval England. In C. M. Woolgar, D. Serjeantson, \& T. Waldron (Eds.), Food in medieval England. Oxford: Oxford University Press.

Ward, L. G., Grizzle, R. E., Bub, F. L., Langan, R., Schnaittacher, G., \& Dijkstra, J. (2001). New Hampshire open ocean aquaculture demonstration project, site description and environmental monitoring report on activities from fall 1997 to winter 2000. Durham, New Hampshire: University of New Hampshire, Jackson Estuarine Laboratory.

Ward, L. G., Grizzle, R. E., \& Irish, J. D. (2006). UNH OOA environmental monitoring program, 2005. CINEMar/Open Ocean Aquaculture Annual Progress Report for the Period from January 01, 2005 to December 31, 2005. Final Report for NOAA Grant No. NA16RP1718, Interim Progress Report for NOAA Grant No. NA04OAR4600155.

Wever, L., Krause, G., \& Buck, B. H. (2015). Lessons from stakeholder dialogues on marine aquaculture in offshore wind farms: Perceived potentials, constraints and research gaps. Marine Policy, 51, 251-259.

Wilson, C. A., \& Stanley, D. R. (1998). Constraints of operating on petroleum platforms as it relates to mariculture: Lessons from research. In R. R. Stickney (Ed.), Joining forces with industry-Open ocean aquaculture (p. 60). Proceedings of the 3rd Annual International Conference, May 10-15, Corpus Christi, Texas. TAMU-SG-99-103, Corpus Christi, Texas Sea Grant College Program. 
Zalmon, I. R., Novelli, R., Gomes, M. P., \& Faria, V. V. (2002). Experimental results of an artificial reef programme on the Brazilian coast north Rio de Janeiro. ICES Journal of Marine Science, 59, 83-87.

Ziegler, A. C. (2002). Hawaiian natural history, ecology and evolution. Honolulu: University of Hawaii Press.

Zink, E. (2013). Hot science, high water. Assembling nature, society and environmental policy in contemporary Vietnam. Copenhagen: Nordic Institute of Asian Studies.

Open Access This chapter is licensed under the terms of the Creative Commons Attribution 4.0 International License (http://creativecommons.org/licenses/by/4.0/), which permits use, sharing, adaptation, distribution and reproduction in any medium or format, as long as you give appropriate credit to the original author(s) and the source, provide a link to the Creative Commons license and indicate if changes were made.

The images or other third party material in this chapter are included in the chapter's Creative Commons license, unless indicated otherwise in a credit line to the material. If material is not included in the chapter's Creative Commons license and your intended use is not permitted by statutory regulation or exceeds the permitted use, you will need to obtain permission directly from the copyright holder.

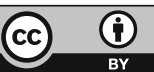

